\title{
Analysis of internal control and its impact on the organizational development of the decentralized autonomous government of the Uzhcurrumi parish
}

\section{Análisis del control interno y su impacto en el desarrollo organizacional del gobierno autónomo descentralizado parroquial Uzhcurrumi}

HERRERA-FREIRE, Alex Humberto $\dagger^{*}$, HERRERA-FREIRE, Alexander Geovanny, JARA-MALLA, Genesis Mishel and YÁNEZ-RÍOS, Katerine Alexandra

Universidad Técnica de Machala, Ecuador

ID $1^{\text {st }}$ Author: Alex Humberto, Herrera-Freire / ORC ID: 0000-0002-3345-8726

ID $1^{\text {st }}$ Co-author: Alexander Geovanny, Herrera-Freire / ORC ID: 0000-0003-4039-1029

ID $2^{\text {nd }}$ Co-author: Genesis Mishel, Jara-Malla / ORC ID: 0000-0002-2648-1194

ID $3^{\text {rd }}$ Co-author: Katerine Alexandra, Yánez-Ríos / ORC ID: 0000-0001-7495-7815

DOI: $10.35429 /$ EJROP.2021.7.13.12.19

Received July 15, 2021; Accepted December 30, 2021

Abstract

This research aims to determine the impact of internal organizational control in the Uzhcurrumi Parish GAD through the investigation of policies and norms that regulate the fulfillment of institutional objectives. For an institution to be competitive and successful in its administration requires transparency, good honorability, good conduct, organization and integrity in the execution of the management system, in addition to constant monitoring of financial, economic and administrative activities. For this reason, the management of internal control is essential for an adequate organizational development, since it guarantees a correct administration and the organizational development of the institution. The methodology applied is the qualitative-descriptive, which is carried out by searching for information that supports the topic addressed, thus allowing the verification of the effectiveness of the control system and its importance in public institutions. Concluding that public entities must have an internal control system as a management tool within the institution.

Internal Control, Organizational Development, Parish GAD

\begin{abstract}
Resumen
La presente investigación tiene como objetivo determinar el impacto del control interno organizacional en el GAD Parroquial Uzhcurrumi a través de la indagación de políticas y normas que regulen el cumplimiento de los objetivos institucionales. Para que una institución sea competitiva y alcance el éxito en su administración se requiere de transparencia, honorabilidad, buena conducta, organización e integridad en la ejecución del sistema de gestión, además es necesario un monitoreo constante de las actividades financieras, económicas y administrativas. Por tal razón el manejo del control interno es fundamental para un adecuado desarrollo organizacional, pues garantiza una correcta administración y el desenvolvimiento organizativo de la institución. La metodología aplicada es la cualitativa-descriptiva, misma que se realiza mediante la búsqueda de información que respalde el tema abordado, permitiendo así la verificación de la efectividad del sistema de control y su importancia en las instituciones públicas. Concluyendo que las entidades públicas deben contar con un sistema de control interno como una herramienta de gestión dentro de la institución.
\end{abstract}

Control Interno, Desarrollo organizacional, GAD parroquial

Citation: HERRERA-FREIRE, Alex Humberto, HERRERA-FREIRE, Alexander Geovanny, JARA-MALLA, Genesis Mishel and YÁNEZ-RÍOS, Katerine Alexandra. Analysis of internal control and its impact on the organizational development of the decentralized autonomous government of the Uzhcurrumi parish. ECORFAN Journal-Republic of Paraguay. 2021. 713:12-19.

\footnotetext{
* Correspondence to Author (E-mail: ahherrera@utmachala.edu.ec)

$\dagger$ Researcher contributing as first author.
} 


\section{Introduction}

The Rural Uzhcurrumi parish was created on January 22, 1971, currently its administration is in charge of Mr. Abraham Joel Sánchez Velepucha. In compliance with the provisions of the first paragraph of article four of the LOTAIP issued by the Congreso Nacional (2004) which states that: "public information belongs to citizens" (p.3), administrators of institutions that are part of the State are obliged to provide their citizens with free and transparent access to public information.

In order to carry out the activities of the institution efficiently and effectively, it is recommended that both public and private organizations implement an Internal Control system, according to Villa et al. (2017) its execution manages to significantly minimize fraud, scams, errors, embezzlement, abuses and crimes allowing to protect the resources of the institutions.

It has been shown that all companies regardless of the context to which they belong need to integrate an Internal Control system that is effective and allows verifying that the processes carried out generate reliability, transparency, efficiency and are focused on compliance with rules, laws and regulations in force (Serrano Carrión et al., 2018). For an institution to be competitive and successful in its administration requires transparency, honorability, good conduct, organization and integrity.

In the execution of the management system, constant monitoring of financial, economic and administrative activities is necessary. The use of internal control is essential for an adequate organizational development since it guarantees a correct organizational development of the institution.

Despite the demonstration of the advantages provided by the use of internal control, there are still organizations in which there is a lack of it, as is the case of the Parish GAD of Uzhcurrumi in which a correct control is not carried out, which according to (Egas Moreno et al. (2019) is due to the fact that the worker has ignorance of how the activities that are in his charge are related to the work done by others and a lack of professional judgment.
Given this problem and the need to obtain a deeper study of the effect generated by internal control, an investigation has been carried out with the aim of determining the impact of the internal organizational control of the Decentralized Autonomous Government of the Uzhcurrumi Parish through the study of policies and norms that regulate the fulfillment of institutional objectives. In the research, a descriptive qualitative methodology is applied, which is carried out by searching for information that supports the topic addressed, which will allow the verification of the effectiveness of the control system and its importance in public institutions.

\section{Internal organizational control}

According to Vivanco Vergara (2017) an internal control system helps to reduce administrative, financial and operational errors allowing optimal decisions to be made within organizations. Among the most common financial errors that allow minimizing internal control are the inadequate distribution of resources, inefficient accounting and the absence of budgetary forecast, which can be corrected within a period of no more than one year when an adequate control is carried out.

An adequate internal control system leads to the segregation of functions, supervision and control of the different levels that are part of the organization, which allows to protect and conserve economic resources, thus avoiding waste, loss, improper use of resources or any act considered illegal, also helps the achievement of the objectives set by the organization and the development of it.

\section{Importance of internal control}

For Ramírez-Casco et al. (2021) obtaining an adequate internal control system is a key factor within organizations since it allows them to carry out a correct evaluation of the processes carried out, which facilitates the use of information and the efficient use of resources.

Internal control gives organizations the opportunity to make correct decisions based on the criteria obtained, providing relative security in the procedures developed. While it is true that internal control can sometimes be affected by a series of limitations, the necessary corrections and constant modifications must be made to adapt the system to the required changes.

HERRERA-FREIRE, Alex Humberto, HERRERA-FREIRE, Alexander Geovanny, JARA-MALLA, Genesis Mishel and YÁNEZ-RÍOS, Katerine Alexand Analysis of internal control and its impact on the organizational Alexich development of the decentralized autonomous government of the Uzhcurrum parish. ECORFAN Journal-Republic of Paraguay. 2021 


\section{Objectives of Internal Control}

According to Emerson (as cited in Calle-Álvarez et al., 2020) the objectives of internal control are informative, compliance and operational. These objectives are aimed at improving the development of activities efficiently, are based on the correct use of information, both financial and non-financial, and focus on compliance with both internal and external regulations.

For a correct internal control, they must establish the objectives based on the following categories: the strategies proposed, the information of operations of a financial nature, compliance with laws, rules, regulations and other legal provisions. These categories comprise a specific topic and together allow to find weaknesses in addition to facilitating the achievement of the goals established in both public and private companies. For MendozaZamora et al. (2018) indicate that the objectives of the categories mentioned in the public sector are:

Encourage the optimization of resources.

Promote transparency, effectiveness and efficiency, both operational and economic.

Improve the quality of goods and services provided by public institutions.

Protect the assets and resources owned by the State to prevent misuse, loss, unlawful acts, deterioration or another unexpected situation.

Promote and encourage the practice of organizational values.

Measure and evaluate the achievement of established goals.

Promote transparency of information issued by public servants and officials who are in charge of assets and funds belonging to the State.

The achievement of the aforementioned objectives allows as a whole to generate in the institutions a culture based on self-control, facilitating in a timely manner the creation of mechanisms and actions of preventive controls.

\section{Internal Control Functions}

The main function of internal control is to allow the efficient and orderly management of the activities carried out within the organization in order to provide reasonable security. According to Mendoza-Zamora et al. (2018) the establishment and operation of internal control depends on the managers, the highest authority and all the personnel that make up the organization, which is why its functions must be oriented in:

- Prevent the waste of institutional resources.

Ensure the implementation and compliance with institutional policies.

Ensure that management within the organization is monitored and periodically monitored.

- $\quad$ Apply measures that avoid risks and errors as much as possible.

- Ensure that the control measures carried out are recorded, in order that the information presented is reliable and allows timely decisions to be made.

\section{Characteristics of internal control}

Camacho Villota et al. (2017) in their publication mention the following characteristics if internal control:

It facilitates the achievement of institutional objectives.

- $\quad$ It generates reasonable security.

- It enables an adequate organizational development.

These characteristics are oriented to the need of companies or institutions to control human resources and their fixed assets. 


\section{Limitations of an internal control system}

In the applicability of internal control, the institutional and/or social objectives to be achieved, the use and reasonable management of public resources, the importance of the budget item in planning and the level of difficulty in its operation must be considered, if these aspects are not considered, it is likely that internal control will be affected and considered deficient (Mendoza-Zamora et al., 2018).

Public sector entities must carry out the rules, procedure manuals and other mechanisms that ensure and endorse the management of internal control. Government agencies that employ state resources should promote principles that build trust and ensure the efficiency and effectiveness of operations based on legal provisions (Gamboa Poveda et al., 2016).

The limitations that can arise in internal control range from the needs that arise in the administration of public entities and the management approach that this represents. In addition, it has been shown that the abuse of authority of some officials are also a limitation, so not only the optimal results of the control must be assessed, but also the compliance with ethical and moral principles of the servers must be guaranteed (Serrano Carrión et al., 2018).

\section{Internal control in parish GADs}

Internal control is of great importance in the management carried out by the parish GADs, since it helps to reduce risk in operations and fosters confidence in the information that is provided for managerial and financial decision making, for this reason it is necessary a good administration and delegate functions to the parties involved in the organization, in addition to following up to verify that the objectives are achieved (Apolo Ordoñez et al., 2019).

The purpose of applying internal control in the public sector is to inform the members of the organization and third parties if the activities are being developed with quality, efficiency and effectiveness, so that the principle of transparency in the use of public resources is evidenced (Gamboa Poveda et al., 2016).

\section{Organizational development}

Pinto Cristiani (2012) indicates that organizational development is fundamental in companies, regardless of the economic activity to which it belongs, if you do not have an adequate organization, you could not face complications regarding internal or external changes in the environment or achieve the achievement of the established purposes which would complicate business growth and competitiveness. With the help of communication strategies and proper administration, activities could be carried out properly.

Some companies due to lack of organization face complicated situations, however, they concentrate most of their resources on external aspects, but not on their internal problems, thus neglecting the fulfillment of activities, which influence the development and growth of the organization, so it is necessary to apply internal control in the administration of the company, to determine the achievement of the proposed objectives (Guerrero \& Mangones, 2016).

\section{Operationalization in organizational development}

Companies are constantly obliged to adapt to new contexts in order to be operational and achieve organizational development, for this they must make changes and transformations that require a significant investment of money and time in addition to a disposition and preparation of human talent (Guarnizo Crespo et al., 2021).

It has been shown that in public institutions change and operationalization are only sought in times of crisis, so organizational development is not as expected. To make the necessary corrections and obtain operationalization in public companies, the focus must be on the modernization and adaptation of their elements, the demands of the population, human talent and productivity. 


\section{Problems generated in the organization}

Cortés (2019) mentions that an appropriate internal control system in the administrative area will allow to know the problems faced by a company and in this way guide the administrators to the correct decision making thus allowing the resolution of current problems and the reduction of future events that threaten the proper functioning of the company.

Within the entities of the public sector there are many problems as an example are the poorly executed administrative processes that originate because the functions carried out by public servants are not controlled generating a breach in planning, organization, direction and control that do not contribute effectively to compliance with the principles of management, that is why improvement strategies must be used to guarantee the well-being and satisfaction of citizens (Troya Andrade et al., 2019).

\section{Organizational competitiveness of internal control}

Using the words of Pinto Cristiani (2012) organizational development allows to face the problems of competitiveness within the organization, in addition it has been shown that a competitive company manages to obtain prestige and credibility; if the company does not achieve a good development, it lags behind in a market where there are many competitors who want to position themselves and achieve growth. In order not to have a decline, there must be the commitment of all individuals, with the intention of fulfilling the activities and achieving the objectives set.

\section{Public Policies}

Participation in public policies fosters the generation of an organization designed for the needs of the population in a social context. It not only tries to link needs to goods and services but also relates them to social practices, values, organizations and political models (Chosco Díaz et al., 2017).

The organizational development process promotes advocacy in public policies, favoring the indispensable conditions to make an effective contribution in response to the problems it addresses and in advancing its organizational compliance (Zamora Aguilar, 2018).

\section{Importance of administrative management}

Mendoza-Zamora et al. (2018) the public sector is oriented in the compliance with legal, constitutional and current laws in order to comply with the objective of public policy focused on the realization of efficient, reasonable and timely reports for decision making; without taking into account careful analysis, based on a political need but not on future results.

González Rodríguez et al. (2020) indicate that it is important to know the elements and processes when incorporating a new administrative management model which allows a preliminary and exhaustive evaluation of the current situation of public entities. In a way that the material and human resources are optimized, allowing each and every one of the processes to be executed with the sole objective of increasing the management of the services with efficiency and quality within the institutions.

\section{Administrative management process}

In the public sector, the interest within the institution is to be equitable in the use of public resources, so directors and officials must be involved in the process of administrative management and follow certain steps that will solve an organizational, management and control problem (González Rodríguez et al., 2020).

Planning and organization is considered as an elementary part in administrative procedures, in which the complexity of the management method is evidenced by presenting various duties and responsibilities. In this process it is best to divide it by subcategories to achieve a flawless, clear and clean procedure that allows you to assume control in management.

It is essential to apply and know these processes that are directed towards direction and leadership, the management model concentrates the results of each phase carried out in the organization, not only in the individual tasks or works (Mendoza-Zamora et al., 2018). 


\section{Elements of administrative management}

For Falconi Piedra et al. (2019) these elements constitute within the administrative management process the essential activities for the administration of the company or institution. The definition of the elements is presented below, in summary manner:

1. Planning: it is the main step in the administrative function, it consists of achieving the objectives in the most efficient way, defining goals and establishing several action resources to achieve what is proposed, it must be developed in a certain time.

2. Organization: It consists of a system that allows to assemble a balanced structure of the business resources to develop the work and achieve the objectives set, that is, to organize and establish a relationship between the personnel and the work that must be executed, to achieve the goals of the organization.

3. Management: It is the function that involves everyone in the organization to comply with the strategies drawn, which contribute to achieve the objectives and goals indicated, this element is focused on the employees and executives of the organization, through leadership, motivation and communication.

4. Control: It consists of controlling the planned activities aligned with the established and planned strategies, through a correct and orderly assessment of the objectives set by the board, with the purpose of correcting any problem and evaluating the results obtained for the decision-making process (MendozaZamora et al., 2018).

\section{Material and Methods}

To achieve the objectives of the research, a qualitative-descriptive methodology is applied, for which a search for information was carried out in scientific journals and reliable sources, the bibliographic review of the literature allowed to collect information regarding the topic addressed allowing to carry out the verification of the effectiveness of the control system and its importance in public institutions.
As for the method used, it can be mentioned that it facilitates the analysis and collection of documentary information for its execution in the research. It is necessary to specify that the results presented demonstrate the functionality of the policies that make up the internal control system (López Jara \& Cañizares Roig, 2018).

\section{Results}

In the parish GAD Uzhcurrumi the existence of government policies and procedures has been evidenced, however, they do not have a manual in which internal control management processes are incorporated and allow to obtain knowledge of the institution and inform the administration or government partners, regarding failures or weaknesses that occur in the activities that are part of the day to day. While it is true that the responsibility that the Parish GAD has an internal control manual that allows it to comply with the proposed institutional objectives and the protection of public resources depends on the highest authorities, the personnel working in the institution must also create the appropriate conditions to ensure that the correct control is executed in the processes applied.

Organizations that have an effective internal control manual manage to minimize costs and allow the good management, custody, control and application of public resources, for this this manual must include the necessary policies and practices that ensure an adequate administration and planning of the institution, so that professional development is guaranteed, transparency and efficiency of material and economic resources.

\section{Discussion}

Authors such as, (Álvarez Magaña et al., 2021; Portal Martínez, 2016; Serrano Carrión et al., 2018; Vivanco Vergara, 2017) indicate that internal control provides reasonable but not absolute security in terms of achieving the organizational objectives proposed by the entities, in the same way they mention that the implementation of the same does not guarantee to change a deficient administration for an adequate one, due to the existence of external factors that organizations cannot control. 
Although the implementation of an internal control does not guarantee absolute security, it was possible to determine through the results obtained that the efficiency of internal control greatly reduces the possibility of not achieving the achievement of organizational objectives in addition to allowing an evaluation of compliance with internal and external regulations, safeguard assets, prevent and determine the commission of fraud and errors but above all ensure that an orderly and efficient conduct of the operational, financial and administrative processes of the organization is carried out.

\section{Conclusions}

The analysis carried out on internal control and its impact on organizational development allowed to generate reliable financial information and minimize risks, for proper decision making, identifying important aspects to achieve the objectives of the parish GAD. The basis of the success of the internal control system is the commitment of its holders and officials, when making changes to existing procedures, these must be clearly defined.

Internal control must have an adequate organizational development, oriented to effectiveness, allowing public institutions to evaluate their performance based on the fulfillment of their goals to transform and grow, achieving effective results in the proposed objectives of the parish GAD.

The assignment of responsibilities of the officials who assume the commitment to help in the control of their processes allows an efficient development in the institution; administrative management is fundamental in the public expenditure cycle, where it formulates, approves, executes and renders the accounts of the public resources that were allocated. Public entities must have an internal control system as a management tool in the institution.

\section{References}

Álvarez Magaña, K. N., Martínez Prats, G., \& García Álvarez, A. D. (2021). La Importancia Del Control Interno En El Área De Ingresos De Una Empresa Comercial. Publicaciones E Investigación, 15(1), 1-11. https://doi.org/https://doi.org/10.22490/253940 88.4692
Apolo Ordoñez, G. M., Narváez Zurita, C. I., \& Erazo Álvarez, J. C. (2019). El Control interno como herramienta de apoyo a la gestión financiera del Gobierno Autónomo Descentralizado Municipal Zaruma. CIENCIAMATRIA, 5(1), 551-577. https://doi.org/10.35381/cm.v5i1.280

Calle-Álvarez, G. O., Narváez-Zurita, C. I., \& Erazo-Álvarez, J. C. (2020). Sistema de control interno como herramienta de optimización de los procesos financieros de la empresa Austroseguridad Cía. Ltda. Dominio de Las Ciencias, 6(1), 429-465. https://dominiodelasciencias.com/ojs/index.php /es/article/view/1155/html

Camacho Villota, W. A., Gil Espinoza, D. J., \& Paredes Tobar, J. A. (2017). Sistema de control interno: Importancia de su funcionamiento en las empresas. Revista Observatorio de La Economía Latinoamericana, http://www.eumed.net/cursecon/ecolat/ec/2017/ control.html

Chosco Díaz, G. C., Fardelli Corropolese, C., \& Anzoátegui, M. (2017). El desarrollo organizacional sustentable de una empresa recuperada: procesos de resiliencia, identidad cooperativa, eficiencia e inclusión social. Revista Argentina de Investigación En Negocios, $3(2)$ 59-70. http://ppct.caicyt.gov.ar/index.php/rain/article/v iew/v3n2-2a05

Congreso Nacional. (2004). Ley General de Transparencia y Acceso a la Informacion Pública. In Registro Oficial Suplemento 337 de 18-may-2004. www.lexis.com.ec

Cortés, A. (2019). El control interno como proceso administrativo para las PYMES. Revista FAECO Sapiens, 2(2), 13-26. https://www.revistas.up.ac.pa/index.php/faeco_ sapiens/article/view/700

Egas Moreno, F. G., Cifuentes, L. M., Toala Preciado, D., \& Vergara Cuadros, Y. N. (2019). Estudio para la implementación del manual de control interno caso (Gobierno Municipal del Cantón Puerto Quito, Provincia de Pichincha). Ciencia Digital, 9(2), 6-26. https://doi.org/10.33262/cienciadigital.v9i2.372 
Falconi Piedra, J. F., Luna Altamirano, K. A., Sarmiento Espinoza, W. H., \& Andrade Cordero, C. F. (2019). Gestión administrativa: Estudio desde la administración de los procesos en una empresa de motocicletas y ensamblajes. Visionario Digital, 3(2), 155-169. https://doi.org/10.33262/visionariodigital.v3i2.4 06

Gamboa Poveda, J., Puente Tituaña, S. P., \& Vera, P. Y. (2016). Importancia del control interno en el sector público. Revista Publicando, $3(8)$, 487-502. https://revistapublicando.org/revista/index.php/ crv/article/view/316

González Rodríguez, S. S., Viteri Intriago, D. A., Izquierdo Morán, A. M., \& Verdezoto Cordova, G. O. (2020). Modelo de gestión administrativa para el desarrollo empresarial del Hotel Barros en la ciudad de Quevedo. Revista Universidad de Cienfuegos, 12(4), 32-37. http://scielo.sld.cu/pdf/rus/v12n4/2218-3620rus-12-04-32.pdf

Guarnizo Crespo, S. F., Tapia Ubillús, A. M., \& Zambrano Farías, F. J. (2021). El desarrollo organizacional como herramienta para el cambio y la mejora de las empresas comerciales de Guayaquil. Opuntia Brava, 13(2), 63-74. http://opuntiabrava.ult.edu.cu/index.php/opunti abrava/article/view/1170

Guerrero, M., \& Mangones, R. (2016). El ambiente de control como mecanismo fundamental en algunas organizaciones comerciales de. Dictamen Libre, 18, 31-39. https://dialnet.unirioja.es/servlet/articulo?codig $\mathrm{o}=5710359$

López Jara, A. A., \& Cañizares Roig, M. (2018). El control interno en el sector público ecuatoriano. Caso de Estudio: gobiernos autónomos descentralizados cantonales de Morona Santiago. Cofin Habana, 12(2), 51-72. http://scielo.sld.cu/scielo.php?script=sci_arttext \&pid=S2073-

$60612018000200004 \& \operatorname{lng}=\mathrm{es} \& \operatorname{tlng}=\mathrm{es}$.

Mendoza-Zamora, W. M., García-Ponce, T. Y., Delgado-Chávez, M. I., \& Barreiro-Cedeño, I. M. (2018). El control interno y su influencia en la gestión administrativa del sector público. Dominio de Las Ciencias, 4(4), 206. https://doi.org/10.23857/dc.v4i4.835
Pinto Cristiani, M. E. (2012). Desarrollo organizacional. In RED TERCER MILENIO S.C.

Portal Martínez, J. M. (2016). Control interno e integridad: elementos necesarios para la gobernanza pública. El Cotidiano, 198, 7-13. http://www.redalyc.org/articulo.oa? $\mathrm{id}=3254680$ 9002

Ramírez-Casco, A. del P., Cedeño-Ávila, G. M., Burbano-Pérez, Á. B., \& Berrones-Paguay, A. V. (2021). Análisis de la aplicación del control interno en la administración pública. Polo Del Conocimiento, 6(6), 923-936. https://doi.org/10.23857/pc.v6i6.2795

Serrano Carrión, P. A., Señalin Morales, L. O., Vega Jaramillo, F. Y., \& Herrera Peña, J. N. (2018). El control interno como herramienta indispensable para una gestión financiera $y$ contable eficiente en las empresas bananeras del cantón Machala (Ecuador). Revista Espacios, 39(3),

30. https://www.revistaespacios.com/a18v39n03/a1 8v39n03p30.pdf

Troya Andrade, R. P., Vásquez Fajardo, C. E., \& Fajardo Vaca, L. M. (2019). Empowerment: una herramienta estratégica como ventaja de competitividad en la administración de los gobiernos autónomos descentralizados (GADS). RECIMUNDO, 3(1), 1110-1135. https://doi.org/10.26820/recimundo/3.(1).enero. 2019.1110-1135

Villa, C., Samaniego, F., \& Ulloa, D. (2017). SISTEMA DE CONTROL INTERNO PARA DETERMINAR EL RIESGO EMPRESARIAL EN LA PROVINCIA DE CHIMBORAZO: CASO GAD CANTON GUANO. Revista De Investigación Talentos, 4(1), 31-38. https://talentos.ueb.edu.ec/index.php/talentos/ar ticle/view/48

Vivanco Vergara, M. E. (2017). Los manuales de procedimientos como herramientas de control interno de una organización. Universidad y Sociedad, 9(2), 247-252. http://rus.ucf.edu.cu/index.php/rus

Zamora Aguilar, M. G. (2018). El desarrollo organizacional como generador de un cambio significativo en las organizaciones de la sociedad civil. Revista Extrameña de Ciencias Sociales “ALAMENARA," 10, 87-109. https://dialnet.unirioja.es/servlet/articulo?codig $\mathrm{o}=6415690$

HERRERA-FREIRE, Alex Humberto, HERRERA-FREIRE, Alexander Geovanny, JARA-MALLA, Genesis Mishel and YÁNEZ-RÍOS, Katerine Alexandra. Analysis of internal control and its impact on the organizational Alex (he Uzhcurrumi parish. ECORFAN Journal-Republic of Paraguay. 2021 